\title{
Management Effectiveness and Potential for Tourism of Peri-Urban Lusaka National Park, Zambia: A Preliminary Assessment
}

\author{
Vincent R. Nyirenda ${ }^{1}$, Victor M. Siamudaala ${ }^{2}$ \& Milimo Kaula ${ }^{1}$ \\ ${ }^{1}$ Directorate of Research, Planning, Information and Veterinary Services, Zambia Wildlife Authority, Chilanga, \\ Zambia \\ 2 The Nature Conservancy, Lusaka, Zambia \\ Correspondence: Vincent R. Nyirenda, Directorate of Research, Planning, Information and Veterinary Services, \\ Zambia Wildlife Authority, Private Bag 1, Chilanga, Zambia. Tel: 260-211-278-365. E-mail: \\ nyirendavr@hotmail.com
}

Received: December 4, 2013 Accepted: February 7, 2014 Online Published: February 20, 2014

doi:10.5539/enrr.v4n1p117 URL: http://dx.doi.org/10.5539/enrr.v4n1p117

\begin{abstract}
Management effectiveness of a park is multi-faceted subject with implications on various aspects of its existence. Determination of the management effectiveness of a protected area is often linked to monitoring processes. Wildlife monitoring is a critical component of wildlife management and integral part of a research programme for Lusaka National Park $\left(49.76 \mathrm{~km}^{2}\right)$. A preliminary study was undertaken to determine the protected area management effectiveness, initially by ascertaining the status and distribution of mega-fauna resources. This was followed by evaluating whether the park management was effective by using status of wildlife populations as surrogate in comparison to initial wildlife stocks. Helicopter and ground line transects, historical data and field patrol data were used for analyses of park's management effectiveness and potential for ecotourism. Though the study has locally relevant findings, insights on persistence factors such as selection of translocated wildlife, resource ecology and management can benefit park ecologists, managers and other stakeholders especially those responsible for smaller parks of less than $100 \mathrm{~km}^{2}$. However, further research is recommended on wider management effectiveness elements to understand factors affecting the park's management effectiveness.
\end{abstract}

Keywords: founder populations, Lusaka National Park, management effectiveness, sustainable tourism, wildlife persistence

\section{Introduction}

Protected areas, which are normally biodiversity 'hotspots', degrade when not effectively managed, to an extent that wildlife species are threatened with local extinctions. Such areas would have natural stocks of wildlife or the wild animals may have been re-introduced after past loss of wildlife or introduced entirely afresh. As pressures and threats on protected areas increase, the concerns and the need for management effectiveness also heighten (Hockings, Stolton, \& Dudley, 2000; Leverington et al., 2010). Evaluating management effectiveness includes delivery of protected area objectives (Hockings, Stolton, Leverington, Dudley, \& Courrau, 2006). In the case of Lusaka National Park, the major purpose for creation of the park was to provide public nature-based tourism to local and international visitors, while protecting the water catchment system together with wildlife resources. Therefore, park management team's objective was to establish the wildlife founder populations for biodiversity conservation and tourism purposes. Therefore, this study sets to evaluate the status of mega-faunal resources of the Lusaka National Park. It provides preliminary findings on how the wildlife in a small national park $(<100$ $\mathrm{km}^{2}$ ) are affected by various persistence factors against the management target of increasing animal diversity and abundance from introduction and re-introduction programmes by the wildlife agency. It starts by ascertaining the wild animal numbers and their distribution, highlighting management issues or threats influencing wildlife persistence. Further, it hypothesises that management effectiveness could improve the park's wildlife persistence.

Monitoring of biodiversity is a critical part of management effectiveness. Estimating wildlife abundance is an important integral part of wildlife research programmes and prerequisite for effective wildlife management (Jachmann, 2001). However, determination of wildlife abundance can be complex (Reilly, 2002; Kruger, Reilly, \& Whyte, 2008). Limiting elements for accurate wildlife determination in the savannah environment include vegetation cover, characteristics of animal species, skills of surveyors and equipment employed. For instance, 
cryptic species may require special attention. The merits for conducting such monitoring activities include acquisition of wildlife demographic information that informs management decision. Thus, knowing what is being managed is an essential part of management (Sen, 1999). Wildlife is managed for various purposes such as photographic tourism, breeding and conservation education programmes. Therefore, methods used to monitor wildlife components will determine whether there is a success or failure in conservation efforts, supporting tourism.

In African savannah, both aerial and ground survey methods have been applied with varying degrees of accuracy and level of sophistication (Jachmann, 2001). They have been undertaken for various reasons, including determination of wildlife population seasonal abundance and distribution (Chase \& Griffin, 2008; Chomba, Simukonda, Nyirenda, \& Chisangano, 2012). However, comparative surveys are rarely executed and evaluated for their effectiveness because the two methods are usually employed under different conditions. Having thoroughly examined five survey methods, Caro (1999) recommends therefore, refraining from comparing aerial to ground survey results. In this study, researchers combine the two methods and utilise the results on complimentary basis.

Data from the aerial and ground surveys and other sources such as field patrols are useful in determining persistence of wildlife. In protected areas, persistence of species in the long term will depend on availability of suitable environmental conditions (Margules \& Pressey, 2000; Parrish, Braun, \& Unnasch, 2003). The environmental conditions may include forage quality, availability, quality and quantity of water and space, status of disease outbreaks and level of protection. These conditions, however, require adaptive and effective management for park's sustenance as a protected area (Hockings, 2003).

\section{Materials and Methods}

\subsection{Description of Lusaka National Park}

The Lusaka National Park No. $20\left(49.76 \mathrm{~km}^{2}\right)$, gazetted on $5^{\text {th }}$ May 2011, is located in the urban peripheral south-east of Lusaka, Zambia (Figure 1). The park is situated in a catchment of over 1.747 million people, with one of the highest average annual rate of human population increase at $4.9 \%$ (Central Statistical Office, 2012). Prior to its establishment, the area was threatened by illegal anthropogenic activities such as wanton settlements, charcoal burning, wanton tree cutting, land cultivation and sand quarrying. Limited management capacity resulted in much pressure exerted on the park. 


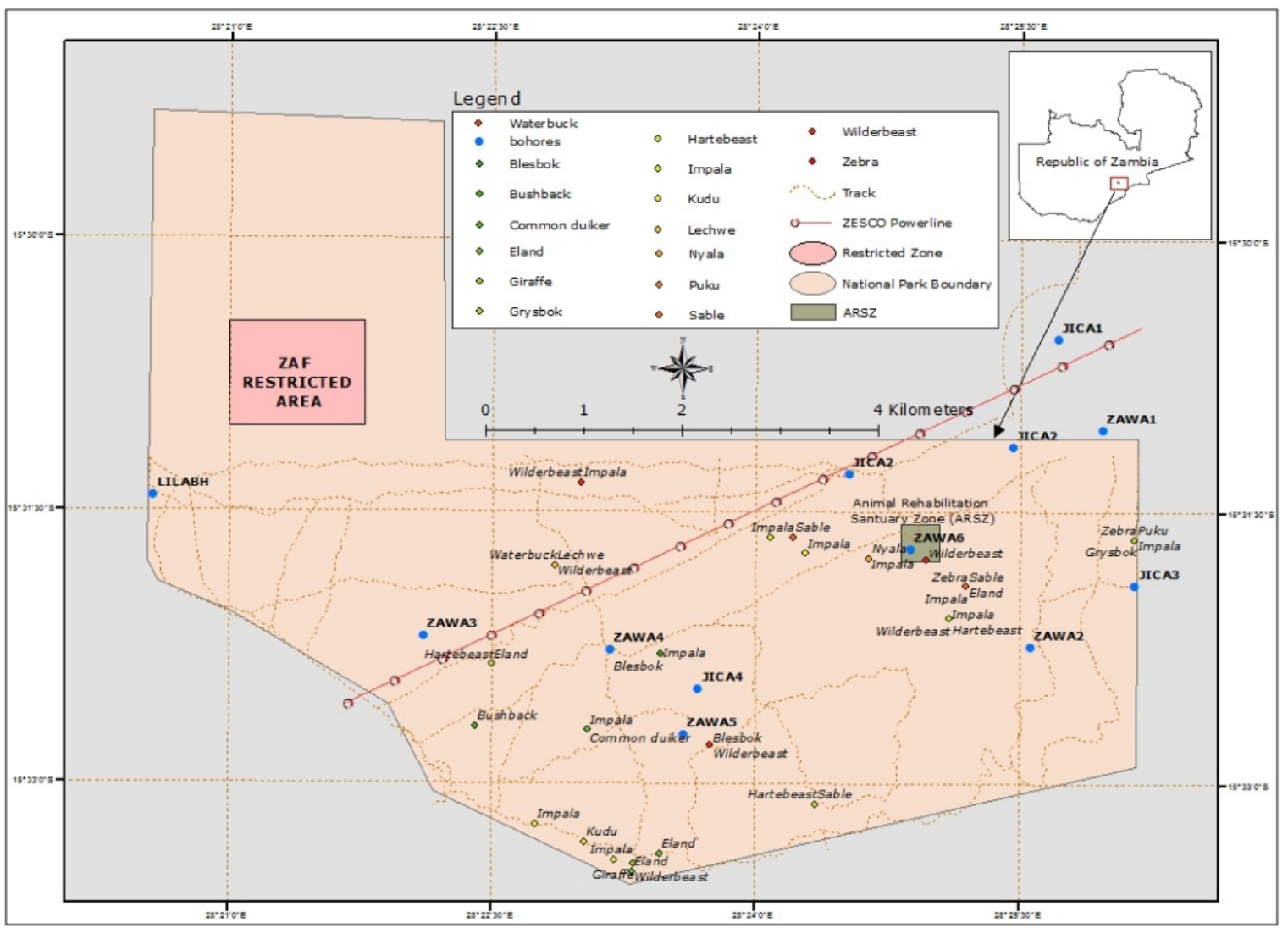

Figure 1. Distribution of animals in Lusaka National Park, Zambia, 2013

The park's annual average temperatures range from $19.7{ }^{\circ} \mathrm{C}$ to $21.3{ }^{\circ} \mathrm{C}$ and rainfall from $482.6 \mathrm{~mm}$ to $1,366.2$ $\mathrm{mm}$ (Yachiyo Engineering Co. Ltd., 1995). Typical climate is dry cool season from April to mid August, hot dry season from mid August to mid November and rain season from mid November to early April. The park has relatively flat terrain, lying between $1,219 \mathrm{~m}$ and $1,488 \mathrm{~m}$ above the sea level, but characterised by the isolated hills that offer unique vantage view shed of the park and Lusaka area.

Underlying the park are layers of limestone and dolomite rocks. Common soil type in southern portion of Lusaka National Park is vertisols while in the northern part of the park, the prevalent soil type is loamy soils. According to Mulenga (1990), the soils of Lusaka National Park can be generally described as moderately well to imperfectly drained, dominantly shallow, dark brown to yellowish brown, slightly acid to moderately acid, coarse to fine loamy soils: eutric leptosols. Hydrology of the park is characterised by limited ephemeral streams and as such for a great part of the year wild animals depend on water extracted from ground water reserves, which is supplied at artificial watering points. The southern part of the park has seasonally inundated wetland, dambo, but its sustainability may be threatened by anthropogenic activities such as sand quarrying on the boundaries of the park. Vegetation communities of the park are characterised by open Brachystegia spp. dominated miombo woodlands interspersed with open bushes and grasslands. Prior to the completion of the park fence in 2008, the trees with an average size greater than $60 \mathrm{~cm}$ in diameter at breast height (DBH) and even lesser were illegally harvested by intruders for charcoal production. There is presence of Lantana camara, an exotic invasive species that has been encroaching into wildlife habitat. Bush encroachment by native Dichrostachys cinerea also poses a threat to the park's wetlands. The park has a variety of grass species but most of them are not palatable by grazers, thereby causing grazers to concentrate in certain areas for grazing.

Only small animal species, such as common duiker (Sylvicapra grimmia, Linnaeus, 1758), persisted there and virtually no mega-fauna as a result of extirpation from poaching, prior to mass translocations of wild animals into Lusaka National Park in 2008. According to Ansell (1978), the area now under Lusaka National Park was previously a rangeland to several wildlife species. Between 2008 and 2012, a total of 799 wild animals had been translocated to the park by the wildlife agency. Before translocations of indigenous and exotic mega-wildlife 
were conducted by wildlife agency, the park was fenced to keep the animals in confinement and thereafter, high presence of wildlife police officer (WPO) at $1.60 \mathrm{~km}^{2} / \mathrm{WPOs}$, under the protection by 31 WPOs was maintained.

\subsection{Aerial Surveys}

A 2-seater H300 helicopter operated by Agair Zambia Ltd. and equipped with Global Positioning System (GPS) was used to conduct aerial surveys on $15^{\text {th }}$ August 2013. Sketch map of the park's main features and infrastructure in addition to historical information on animal distribution was employed to orient animal counting transects (Peterman, Crawford, \& Kuhns, 2013). The Pilot/Observer was seated on the Left Hand Side (LHS) and the Observer/Recorder on the Right Hand Side (RHS) of the Helicopter.

A total count method (Craig, 2012; Dunham, 2012) was applied on 40 North-South transects, with reciprocal-overlapping swathes of visibility covering the entire park. Thus, due to small size of the park systematic reconnaissance flights and transact sampling methods (Jolly, 1969; Caughley, 1977; Norton-Griffins, 1978), commonly used in aerial surveys in savannah ecosystems were not adopted. Use of helicopter on relatively short distances and high frequency of north-south transects allowed each observer to identify individuals or groups of animals that crossed the flight paths into consecutive uncounted swathes, enabling crossing animals to be ignored on the reciprocal transects. Coordinated communications between LHS and RHS Observers reinforced the undertaking not to over-count animals by inclusion of animals that traversed transects. Further, use of helicopter allowed for greater probability of spotting animals that might otherwise have been missed if other survey methods were employed. Despite the relatively flat open terrain and scrubby vegetation of the park, it was anticipated that aerial survey would yield under-estimates of animal numbers, especially of the smaller and more cryptic species such as duikers. Where possible, the helicopter was used to herd groups of animals fleeing towards uncounted transect swathes back to the "counted" side of the flight paths. All the sightings were recorded on data form and summarised in Table 1.

Table 1. Aerial and ground surveys results of Lusaka National Park, Zambia, conducted on $15^{\text {th }}$ August 2013 and $23^{\text {rd }}$ July 2013 respectively

\begin{tabular}{|c|c|c|c|c|c|}
\hline $\begin{array}{l}\text { Species / } \\
\text { Transect }\end{array}$ & Scientific Name & $\begin{array}{c}\text { Aerial Surveys: } \\
\text { Total per } \\
\text { Species }\end{array}$ & $\begin{array}{l}\text { Aerial Surveys: } \\
\text { Frequency of } \\
\text { sighting (median in } \\
\text { paranthesis) }\end{array}$ & $\begin{array}{c}\text { Ground } \\
\text { Surveys: Total } \\
\text { per Species }\end{array}$ & $\begin{array}{l}\text { Ground Surveys: } \\
\text { Frequency of } \\
\text { sighting (median in } \\
\text { paranthesis) }\end{array}$ \\
\hline Blesbok & $\begin{array}{c}\text { Damaliscus pygargus } \\
\text { phillipsi (Harper, 1939) }\end{array}$ & 26 & $1(1)$ & 2 & $2(1)$ \\
\hline Bushbuck & $\begin{array}{l}\text { Tragelaphus scriptus } \\
\quad \text { (Pallas, 1766) }\end{array}$ & 11 & $7(1)$ & 2 & $1(2)$ \\
\hline Bushpig & $\begin{array}{l}\text { Potamochoerus larvatus } \\
\text { (Cuvier, 1822) }\end{array}$ & 2 & $1(2)$ & - & - \\
\hline Duiker & $\begin{array}{l}\text { Sylvicapra grimmia } \\
\text { (Linnaeus, 1758) }\end{array}$ & 4 & $3(1)$ & 1 & $1(1)$ \\
\hline Eland & $\begin{array}{c}\text { Taurotragus oryx (Pallas, } \\
1766)\end{array}$ & 35 & $5(4)$ & 17 & $4(4)$ \\
\hline Giraffe & $\begin{array}{l}\text { Giraffa camelopardalis } \\
\quad \text { (Linnaeus, 1758) }\end{array}$ & 8 & $1(8)$ & 8 & $2(4)$ \\
\hline Grysbok & $\begin{array}{l}\text { Raphicerus melanotis } \\
\text { (Thunberg, 1811) }\end{array}$ & - & - & 1 & $1(1)$ \\
\hline Hartebeest & $\begin{array}{c}\text { Alcelaphus lichtensteinii } \\
\text { (Peters, 1849) }\end{array}$ & 22 & $6(3)$ & 11 & $4(3)$ \\
\hline Impala & $\begin{array}{c}\text { Aepyceros melampus } \\
\text { (Lichtenstein, 1812) }\end{array}$ & 48 & $8(4)$ & 97 & $12(4)$ \\
\hline Kudu & $\begin{array}{c}\text { Tragelaphus strepsiceros } \\
\text { (Pallas, 1766) }\end{array}$ & 29 & $9(3)$ & 5 & $1(5)$ \\
\hline
\end{tabular}




\begin{tabular}{|c|c|c|c|c|c|}
\hline Lechwe & $\begin{array}{c}\text { Kobus leche (Lydekker, } \\
1900)\end{array}$ & 12 & $3(3)$ & 1 & $1(1)$ \\
\hline Nyala & $\begin{array}{l}\text { Tragelaphus angasii } \\
\quad \text { (Angas, 1849) }\end{array}$ & 2 & $2(1)$ & 1 & $1(1)$ \\
\hline Puku & $\begin{array}{c}\text { Kobus vardonii } \\
\text { (Livingstone, 1857) }\end{array}$ & 10 & $5(1)$ & 9 & $1(9)$ \\
\hline Reedbuck & $\begin{array}{l}\text { Redunca arundinum } \\
\text { (Boddaert, 1785) }\end{array}$ & 6 & $3(2)$ & - & - \\
\hline Sable & $\begin{array}{l}\text { Hippotragus niger } \\
\text { (Harris, 1838) }\end{array}$ & 44 & $16(3)$ & 33 & $3(11)$ \\
\hline Warthog & $\begin{array}{c}\text { Phacochoerus africanus } \\
\text { (Gmelin, 1788) }\end{array}$ & 10 & $3(4)$ & - & - \\
\hline Waterbuck & $\begin{array}{l}\text { Kobus ellipsiprymnus } \\
\text { (Ogilbyi, 1833) }\end{array}$ & 16 & $7(1)$ & 4 & $2(2)$ \\
\hline Wildebeest & $\begin{array}{c}\text { Connochaetes taurinus } \\
\text { (Burchell, 1823) }\end{array}$ & 106 & $13(8)$ & 129 & $9(8)$ \\
\hline Zebra & $\begin{array}{c}\text { Equus quagga } \\
\text { (Boddaert, 1785) }\end{array}$ & 37 & $3(7)$ & 20 & $3(7)$ \\
\hline Total & & 428 & - & 341 & - \\
\hline
\end{tabular}

The transect flights avoided flying over or close to the white rhinoceros (Ceratotherium simum simum, Burchell, 1817) bomas and enclosures in the Animal Rehabilitation and Sanctuary Zone (ARSZ) (Figure 1). The rhinoceros had earlier been restricted to the feeding bomas in order to minimise the possibility of their being disturbed by the survey flights. Therefore, the counting of the only two white rhinoceros in the boma was excluded from the surveys. A total of 4.6 hours of survey flight time were conducted between 07:00 hours and 11:00 hours (Local Time). Out of 4.6 hours, 3.4 hours were survey time. Within the survey time, 0.3 hours were used to verify the location and numbers of relatively large groups of blesbok (Damaliscus pygargus phillipsi, Harper, 1939) and a single group of giraffe (Giraffa camelopardalis, Linnaeus, 1758), counted earlier. Correction factor was, therefore, established for the missed animals. In addition, positioning time from the helicopter's base was 1.2 hours.

\subsection{Ground Surveys}

The total ground survey count was conducted on $23^{\text {rd }}$ July 2013 with the help of six field assistants equipped with binoculars, following design exercise for establishing line transects based on visibility range from each line transect. Direct counts by use of vehicle and walking line transects were used as postulated by Varman and Sukumar (1995) and Pramod, Kumara, and Gowda (2012), based on open and flat terrain and relatively low budgetary allocation. Where animals were not sighted, indirect signs such as animal tracks and dung piles were noted to record the presence of particular animals (C. Stuart \& M. Stuart, 2013). The layout of 22 line transects was made with overlapping visibility such that distance in between line transects varied from one set of neighbouring line transects to other. Therefore, due to relatively small size of the park, line transect sampling methodology suitable for relatively larger strata (Plumptre, 2000; Craig, 2012), was not applied. All animal sightings were recorded on data forms by the survey team and summarised in Table 1.

\section{Results}

\subsection{Animal Counts From Aerial and Ground Surveys}

The results of aerial and ground animal counts in Table 1 were significantly different for species observations above $1\left(x^{2}=82.67\right.$, d.f. $\left.=11 ; \mathrm{p}<0.001\right)$. However, sightings during field patrols were significantly correlated to those made by aerial and ground surveys per species combined, excluding observations of 1 or less made using either aerial or ground count method $\left(\chi^{2}=87.685\right.$; d.f. $\left.=22 ; p<0.001\right)$. Aerial survey underestimated by average ratio of $1.29 \pm 0.01$ while ground survey underestimated wildlife population even more, depending on visibility. Aerial survey yielded 428 head counts while ground surveys estimated 341 wild animals. From aerial surveys, 18 species were sighted. Sable (Hippotragus niger, Harris, 1838) and blue wildebeest (Connochaetes taurinus, Burchell, 1823) were frequently sighted species, with sighting frequency of 16 and 13 respectively (Table 1 ). 
Blue wildebeest were most visible and widespread species due to body size, colour, and they flushed and fled readily at the approach of the helicopter. Others were giraffe, plains zebra (Equus quagga, Boddaert, 1785), common eland (Taurotragus oryx, Pallas, 1766) and greater kudu (Tragelaphus strepsiceros, Pallas, 1766), though to lesser extents than blue wildebeest. Lusaka National Park has only eight giraffe, frequently sighted in a single group by field staff but only seven were sighted and counted in one group during initial transect flight. Second flight aimed at verifying the count was conducted and yielded a count of eight, giving a correction factor for the giraffe of 1.14. Similarly, initial helicopter flight estimated 18 blesbok in a single group in the east-central area of the park and the repeat verification flight yielded 26 blesbok, with a correction factor of 1.44. Patrol field data revealed that blesbok are usually seen in two large discrete groups as well as smaller dispersed groups or individuals, frequently in the vicinity of the ARSZ, avoided in both aerial and ground surveys so that rhinoceros restrained there were not alarmed. This result shows that blesbok were underestimated. The other large group frequently sighted to the west of the park was not observed during aerial flights. Only two nyala (Tragelaphus angasii, Angas, 1849) were seen during the aerial survey. However, nyala concentrations were usually seen on field patrols in the ARSZ, as the case with blesbok.

Impala (Aepyceros melampus, Lichtenstein, 1812), sable and hartebeest (Alcelaphus lichtensteinii, Peters, 1849) were less easily flushed and put to flight by the helicopter, leading to their lower visibility and greater under-estimates of these species. Impala were seen, in hotter part of the morning's flying, to congregate under the deep shade of Brachystegia spp. trees found in the park, and were reluctant to leave this cover.

From the ground survey, 17 animal species were sighted and counted (Table 1). Impala and blue wildebeest were the most frequently sighted wildlife, with sighting frequency of 12 and 9 respectively. Like during the aerial survey, distribution of animals was skewed to south-western and north-eastern parts of the park (Figure 1). The ARSZ area on the eastern most part of the park had the most diverse and the highest number of animals during the ground count. The area had a mixture of giraffe, sable, impala, zebra, hartebeest, nyala and blue wildebeest. Only black lechwe (Kobus leche, Lydekker, 1900) and blue wildebeest were seen on the western side of the park, probably due to limited watering points.

\section{Discussion}

\subsection{Monitoring of Wildlife Populations for Conservation and Tourism}

This study revealed that aerial survey was complementary to ground survey. For example, though aerial survey cost more than 20 times (USD 4000 by aerial survey to USD 250 for ground survey) ground survey for Lusaka National Park, aerial survey completely missed grysbok present in the park probably due to its small size. Further, even if detection of wild animals improved from elevated vantage in aerial survey, more cryptic and smaller species such as bushbuck (Tragelaphus scriptus, Pallas, 1766), reedbuck (Redunca arundinum, Boddaert, 1785), common duiker, warthog (Phacochoerus africanus, Gmelin, 1788) and bushpig (Potamochoerus larvatus, Cuvier, 1822) were underestimated. Similarly, bushpig, reedbuck and warthog were missed out by ground survey partly due to limited visibility from ground survey. For future surveys, detection rates may improve by use of novel technologies such as 'forward-looking infrared' (FLIR) (Storm et al., 2011).

The ecological elements in Lusaka National Park are one critical persistence factor for wildlife species, The park does not have an abundance of high nutritional value grasses, hence high congregations of animals particularly in the south-eastern part of the park (constituting about $1 / 3$ ). In this area were sprouting grasses, following some early burning. Since the burnt patches were as a result of wanton and unplanned fires that originated from outside the park, there was a need to plan, design and implement fire management plan that considers habitat management. In addition to use of fire for habitat manipulation, well executed fires can be used to reduce tick burden in wildlife populations (van Wilgen, Everson, \& Trollope, 1990). However, sentinel herd systems can also be utilised for control of ticks in wildlife (Racloz, Griot, \& Stärk, 2006). Caution must be made to put some fire breaks prior to use of fire along the fence line to prevent it from damage from excessive heat, affecting insulators and wire straining. In the north western part of the park, where the park was previously relatively more desolate, there has been eventual restoration of vegetation.

Though Lusaka National Park has high density of water holes ( 1 every $\left.3.83 \mathrm{~km}^{2}\right)$, more than $70 \%$ of sightings of wildlife and habitat utilisation were within $500 \mathrm{~m}$ of proximity to the water hole. $12.98 \%(\mathrm{n}=17)$ of wild game animal mortalities are attributed to water unavailability, while $9.16 \%(\mathrm{n}=12)$ to translocation related stress and the rest $(54.20 \%, \mathrm{n}=71)$ to natural causes (Table 2). Unavailability of water to wild animals in certain areas of the park could be a result of poor designs of water holes (Figure 1). Bothma and Du Toit (2010) has given insights into designing and making available and ease access of water to wild animals with minimal negative impacts on wildlife and environment. These take into consideration of drinking patterns and behaviour of 
particular animals. Further, given that most wild game $(59.54 \% ; \mathrm{n}=78)$ died within $300 \mathrm{~m}$ from the park fence, fencing may have negative impacts on animal dispersal especially during the dry season as also stipulated by Martin (2003) and Lindsey, Masterson, Beck, and Romañach (2012).

Table 2. Animals translocated into Lusaka National Park, Zambia: their sources and mortalities, 2008-2013

\begin{tabular}{|c|c|c|c|c|c|c|c|c|}
\hline \multirow{2}{*}{$\begin{array}{l}\text { Common } \\
\text { Name }\end{array}$} & \multirow{2}{*}{ Scientific Name } & \multicolumn{3}{|c|}{$\begin{array}{c}\text { Translocations } \\
(2008-2013)\end{array}$} & \multirow{2}{*}{ Origin } & \multirow{2}{*}{$\begin{array}{l}\text { Mortalities } \\
(2008-2013)\end{array}$} & \multirow{2}{*}{$\begin{array}{c}\% \\
\text { Mortality }\end{array}$} & \multirow{2}{*}{$\begin{array}{l}\text { Causes of } \\
\text { mortalities }\end{array}$} \\
\hline & & Male & Female & Total & & & & \\
\hline $\begin{array}{l}\text { Angolan } \\
\text { Giraffe }\end{array}$ & $\begin{array}{c}\text { Giraffa } \\
\text { camelopardalis } \\
\text { (Linnaeus, 1758) }\end{array}$ & 4 & 3 & 7 & $\begin{array}{l}\text { Chaminuka Game } \\
\text { Ranch\& Kafue } \\
\text { National Park, } \\
\text { Zambia }\end{array}$ & 1 & 14.29 & Natural \\
\hline $\begin{array}{l}\text { Black } \\
\text { lechwe }\end{array}$ & $\begin{array}{c}\text { Kobus leche } \\
\text { (Lydekker, 1900) }\end{array}$ & 5 & 12 & 17 & $\begin{array}{l}\text { State House, } \\
\text { Zambia }\end{array}$ & 13 & 76.47 & Natural \\
\hline Blesbok & $\begin{array}{c}\text { Damaliscus } \\
\text { pygargus Phillipsi } \\
\text { (Harper, 1939) }\end{array}$ & - & - & 50 & $\begin{array}{c}\text { Kimberly, South } \\
\text { Africa }\end{array}$ & 6 & 12.00 & $\begin{array}{l}\text { Inadequate } \\
\text { water and } \\
\text { food }\end{array}$ \\
\hline Bushbuck & $\begin{array}{c}\text { Tragelaphus } \\
\text { scriptus (Pallas, } \\
1766)\end{array}$ & 6 & 22 & 28 & $\begin{array}{l}\text { Lilayi \& Chaminuka } \\
\text { Game Ranches }\end{array}$ & 6 & 21.43 & $\begin{array}{l}\text { One drowned } \\
\text { in water } \\
\text { trough; others } \\
\text { unknown }\end{array}$ \\
\hline Eland & $\begin{array}{l}\text { Taurotragus oryx } \\
\text { (Pallas, 1766) }\end{array}$ & 5 & 27 & 32 & $\begin{array}{c}\text { Chaminuka Game } \\
\text { Ranch; Mazabuka, } \\
\text { Zambia }\end{array}$ & 3 & 9.38 & Natural \\
\hline Hartebeest & $\begin{array}{c}\text { Alcelaphus } \\
\text { lichtensteinii } \\
\text { (Peters, 1849) }\end{array}$ & 3 & 13 & 16 & $\begin{array}{c}\text { Chaminuka Game } \\
\text { Ranch; Mazabuka, } \\
\text { Zambia }\end{array}$ & 2 & 12.50 & Natural \\
\hline Impala & $\begin{array}{c}\text { Aepyceros } \\
\text { melampus } \\
\text { (Lichtenstein, } \\
\text { 1812) }\end{array}$ & 76 & 126 & 202 & $\begin{array}{l}\text { Chilanga Golf Club; } \\
\text { Kafue Fisheries; } \\
\text { State House; } \\
\text { Chaminuka, Zambia }\end{array}$ & 24 & 11.88 & Natural \\
\hline Kudu & $\begin{array}{c}\text { Tragelaphus } \\
\text { strepsiceros } \\
\text { (Pallas, 1766) }\end{array}$ & 3 & 17 & 20 & Kitwe, Zambia & 2 & 10.00 & Natural \\
\hline Nyala & $\begin{array}{c}\text { Tragelaphus } \\
\text { angasii (Angas, } \\
1849)\end{array}$ & - & - & 28 & $\begin{array}{c}\text { Kimberly, South } \\
\text { Africa }\end{array}$ & 10 & 35.71 & Natural \\
\hline Pangolin & $\begin{array}{c}\text { Manis spp. } \\
\text { (Desmarest, 1822) }\end{array}$ & - & - & 1 & Mazabuka, Zambia & 0 & 0.00 & - \\
\hline Puku & $\begin{array}{c}\text { Kobus vardonii } \\
\text { (Livingstone, } \\
\text { 1857) }\end{array}$ & 10 & 39 & 49 & $\begin{array}{c}\text { Chaminuka Game } \\
\text { Ranch; Mazabuka, } \\
\text { Zambia }\end{array}$ & 12 & 24.49 & Natural \\
\hline Reedbuck & $\begin{array}{c}\text { Redunca } \\
\text { arundinum } \\
\text { (Boddaert, 1785) }\end{array}$ & 1 & 9 & 10 & $\begin{array}{c}\text { Chaminuka Game } \\
\text { Ranch; Mazabuka, } \\
\text { Zambia }\end{array}$ & 0 & 0.00 & - \\
\hline $\begin{array}{c}\text { Sable } \\
\text { antelope }\end{array}$ & $\begin{array}{c}\text { Hippotragus niger } \\
\text { (Harris, 1838) }\end{array}$ & 9 & 11 & 20 & $\begin{array}{l}\text { Masebe Game } \\
\text { Ranch }\end{array}$ & 4 & 20.00 & Natural \\
\hline
\end{tabular}




\begin{tabular}{|c|c|c|c|c|c|c|c|c|}
\hline & & & & & Mundawanga & & & \\
\hline $\begin{array}{l}\text { Spotted } \\
\text { Deer }\end{array}$ & $\begin{array}{c}\text { Axis axis (Erxleben, } \\
1777)\end{array}$ & 1 & 1 & 2 & $\begin{array}{l}\text { Zoological and } \\
\text { Gardens Park, } \\
\text { Zambia }\end{array}$ & 0 & 0.00 & - \\
\hline Warthog & $\begin{array}{c}\text { Phacochoerus } \\
\text { africanus (Gmelin, } \\
1788)\end{array}$ & - & - & 20 & $\begin{array}{l}\text { Chaminuka Game } \\
\text { Ranch, Zambia }\end{array}$ & 6 & 30.00 & $\begin{array}{l}\text { Inadequate } \\
\text { water and } \\
\text { food }\end{array}$ \\
\hline Waterbuck & $\begin{array}{c}\text { Kobus } \\
\text { ellipsiprymnus } \\
\text { (Ogilbyi, 1833) }\end{array}$ & 6 & 14 & 20 & $\begin{array}{c}\text { Lilayi Game Ranch; } \\
\text { Chaminuka Game } \\
\text { Ranch; Mazabuka, } \\
\text { Zambia }\end{array}$ & 3 & 15.00 & $\begin{array}{l}\text { Inadequate } \\
\text { water and } \\
\text { food }\end{array}$ \\
\hline $\begin{array}{c}\text { White } \\
\text { rhinoceros }\end{array}$ & $\begin{array}{l}\text { Ceratotherium } \\
\text { simum simum } \\
\text { ( Burchell, 1817) }\end{array}$ & 1 & 1 & 2 & $\begin{array}{c}\text { Kimberly, South } \\
\text { Africa }\end{array}$ & 0 & 0.00 & - \\
\hline Wildebeest & $\begin{array}{c}\text { Connochaetes } \\
\text { taurinus (Burchell, } \\
1823 \text { ) }\end{array}$ & - & - & 202 & $\begin{array}{c}\text { Kimberly, South } \\
\text { Africa }\end{array}$ & 27 & 13.37 & $\begin{array}{l}\text { One drowned } \\
\text { in water } \\
\text { trough; others } \\
\text { unknown }\end{array}$ \\
\hline Zebra & $\begin{array}{c}\text { Equus quagga } \\
\text { (Boddaert, 1785) }\end{array}$ & 15 & 58 & 73 & $\begin{array}{c}\text { Chaminuka Game } \\
\text { Ranch; Blue Lagoon } \\
\text { National Park, } \\
\text { Zambia }\end{array}$ & 12 & 16.44 & $\begin{array}{l}\text { Translocation } \\
\text { related stress }\end{array}$ \\
\hline Total & & 145 & 353 & 799 & & 131 & 16.40 & \\
\hline
\end{tabular}

Due to high demand for bushmeat (Poulsen, Clark, Mavah, \& Elkan, 2009; Lindsey et al., 2013), as is the case in many of African protected areas, poaching is another persistence factor to wildlife in Lusaka National Park. Of various methods used in poaching, snaring of wild animals still remains common in buffer zones around national parks (Watson, Becker, McRobb, \& Kanyembo, 2013). Snaring of wild animals is non-selective (Lewis \& Phiri, 1998; Becker et al., 2013) and has been a major threat to the wildlife populations of Lusaka National Park. Large mammals of size larger than common waterbuck (Kobus ellipsiprymnus, Ogilbyi, 1833) are most targeted due to the large amounts of bushmeat they avail for commercial purposes (Craigie et al., 2010). Hitherto, though unquantified number of wires used in snaring have been removed in the peripherals of Lusaka National Park, the number of wildlife that could have been poached by this means and the number of wild animals that could have escaped through the park fence is unknown. Lusaka City with relatively high human population (Central Statistical Office [CSO], 2012), provides potentially readily available markets for bushmeat. Therefore, management effectiveness of protected areas such Lusaka National Park will depend on levels of protection invested (Caro et al., 1998).

Drawing insights from Bandyopadhyay and Tembo (2010) that local communities living in proximity to protected areas support wildlife initiatives better when they perceive and receive benefits from wildlife, it is proposed that communities surrounding the Lusaka National Park be facilitated to derive adequate benefits. The facilitation could include development of partnerships and entrepreneurships, particularly for Shantumbu communities in the southern part of the park who historically depended on the park area for agricultural land, charcoal production, timber harvesting, sand quarrying and harvest of non-forest products such as mushrooms. Consequently, their involvement in tourism development can support positive perception towards the park (Snyman, 2012). Other innovations such as contractual parks (Reid, 2001), managed by non-state actors could be considered to increase park management effectiveness, with suitable collaborative governance and adequate benefit sharing between contracting parties (Nyirenda \& Nkhata, 2013).

\subsection{Park's Management Effectiveness}

The park management team's objective was to establish viable wildlife founder populations for biodiversity conservation and tourism purposes. The key indicator of their management performance was wildlife abundance and persistence of each species that has either been introduced or re-introduced in Lusaka National Park. We attribute the abundance and persistence of wildlife in Lusaka National Parks to management effectiveness, 
explained by various elements such as selection of wildlife species for re-introduction and introduction, and habitat management. By using wildlife population counts, numerical approaches to determining management effectiveness aided the analysis and could be an important instrument for decision-making (Rivero-Blanco \& Gabaldon, 1999). As the management effectiveness requires appropriate, accurate and timely reporting for effective protected area management (Stolton et al., 2007), well designed and implemented animal counts are critical. Several approaches exist for evaluating management effectiveness and may also make a combination of elements like threats, biodiversity significance, integrity and management depending on the purpose and scope of the study (The Nature Conservancy, 2000; Ervin, 2003; Blom, Yamindou, \& Prins, 2004; Hockings et al., 2006).

Selection of wildlife species for translocation congruent to suitability of recipient wildlife habitat is critical aspects of managing introduced wild animals (Bothma \& Du Toit, 2010) as well as determination of habitat suitability for animals (Sinclair, Fryxell, \& Caughley, 2009; Freemantle, Wacher, Newby, \& Pottorelli, 2013). Lusaka National Park has several exotic and out-of-range species that were introduced there for tourism purposes These include nyala, blesbok, grysbok, blue wildebeest and spotted deer. Introduction of exotic and out-of-range species poses several management challenges and may compromise habitat integrity (Matthews \& Brand, 2004; Simons \& De Poorter, 2008). Especially where habitat conditions have not significantly been altered, the selection of wildlife species for translocation should be based on historical information on existence of animals such as provided by Ansell (1978). In addition, the recipient habitats for introduced animals should be suitable. However, habitat manipulation can be carefully conducted but usually at a great cost. Due to limitation of availability of aquatic environments, mortalities in nyala, lechwe, puku (Kobus vardonii, Livingstone, 1857) and waterbuck, which are hydrophilic, have been high $(47.33 \% ; n=62)$ especially during dry seasons. Persistence of herpetofauna and other forms of biological resources could also be influenced by water availability. Mifsud and Thomas (2013) observed that in urbanised Rouge River ecosystem, amphibian and reptile species richness were associated with wetland size and hydro-period. Other biological aspects such as fecundity are also likely to be affected negatively by degrading habitat conditions and consequently, reducing wildlife population growth and tourism potential in long term. Some animals such as Zebras have also died as a result of translocation related stress (Table 2). Therefore, animal translocations need to be accompanied by effective planning and implementation. Wildlife translocations have over time been successful if conducted under suitable conditions, by eliminating chances of loosing animals during and shortly (within 24 hours) after release (Garaï, Slotow, Carr, \& Reilley, 2004). Despite some shortcomings, current wildlife species diversity and biomass in Lusaka National Park in comparison to other national parks in Zambia have high potential to attract nature based tourists progressively once opened to public use (Table 3). Further, management plan for the Lusaka National Park could be enhanced to set forth detailed management agenda for managing ecological, law enforcement, research, educational and tourism aspects in order to increase resilience of wildlife to various threats and management effectiveness.

Table 3. Wildlife species diversity, biomass and tourism arrivals in key Zambia's National Parks

\begin{tabular}{cccccccc}
\hline National Park & $\begin{array}{c}\text { No. } \\
\text { Species }\end{array}$ & $\begin{array}{c}\text { Biomass } \\
\left(\mathrm{kg} / \mathrm{km}^{2}\right)\end{array}$ & $\begin{array}{c}\text { Arrivals in } \\
2009^{* *}\end{array}$ & $\begin{array}{c}\text { Arrivals in } \\
2010^{* *}\end{array}$ & $\begin{array}{c}\text { Arrivals in } \\
2011^{* *}\end{array}$ & $\begin{array}{c}\text { Arrivals in } \\
2012^{* *}\end{array}$ & $\begin{array}{c}\text { \% Change in } \\
\text { Arrivals } \\
(2009-2012)\end{array}$ \\
\hline Mosi-oa-tunya & 12 & $6,902.18$ & 3,099 & 4,519 & 7,352 & 14,659 & 373.02 \\
Kafue & 23 & $1,210.35$ & 5,507 & 6,762 & 9,252 & 5,461 & $(0.84)$ \\
South Luangwa & 19 & $3,163.17$ & 9,254 & 18,019 & 29,526 & 35,480 & 283.40 \\
Lower Zambezi & 9 & 900.89 & 21,891 & 28,186 & 16,481 & 6,937 & $(68.31)$ \\
Lusaka* & 22 & $2,493.19$ & - & - & - & - & - \\
\hline
\end{tabular}

*Not yet opened to public use.

**Data was sourced from Zambia Wildlife Authority records.

\section{Conclusion}

Preliminary assessment of management effectiveness has been conducted by using field surveys and patrol data in comparison to historical animal translocations data for the newly established Lusaka National Park. Such 
analysis, though, with great local relevance can benefit wider community of researchers and practitioners especially on how local context and management outputs can be used for identifying issues influencing wildlife species quantum and persistence, and possibly, local tourism. Similarly, previous studies have for instance shown that the threat reduction assessments can play a role in decision making for management effectiveness in protected areas (Salafsky \& Margoluis, 1999; Parrish et al., 2003; Struhsaker \& Jacobson, 2004). Therefore, by utilising results of monitoring programmes, management responses could be strategic and adaptive to changing socio-economic-ecological factors that may affect the park. From this initial assessment, we propose further research on wider management effectiveness elements to understand factors affecting the park's management effectiveness.

\section{Acknowledgements}

The study was supported by Zambia Wildlife Authority. The following people took part in animal counts: Richard Jeffery, John Myers, Anastasia Kilundo, Mathews Mvula, Yusuf Simuunza, Musonda Mwela and Daniel Mwanza. Authors are indebted to Erastus Kancheya, Area Warden and Trevor Silwamba, Park Ranger for their invaluable assistance during data collection period. The map in Figure 1 was produced by Mr. Benson Kabungo, to whom we are also grateful.

\section{References}

Ansell, W. F. H. (1978). The mammals of Zambia. Chilanga: National Parks and Wildlife Service.

Bandyopadhyay, S., \& Tembo, G. (2010) Household consumption and natural resource management around national parks in Zambia. Journal of Natural Resources Policy Research, 2, 39-55. http://dx.doi.org/10.1080/19390450903350838

Becker, M., McRobb, R., Watson, F., Droge, E., Kanyembo, B., Murdoch, J., \& Kakumbi, C. (2013). Evaluating wire-snare poaching trends and the impacts of by-catch on elephants and large carnivores. Biological Conservation, 158, 26-36. http://dx.doi.org/10.1016/j.biocon.2012.08.017

Blom, A., Yamindou, J., \& Prins, H. H. T. (2004). Status of protected areas of the Central African Republic. Biological Conservation, 118, 479-487. http://dx.doi.org/10.1016/j.biocon.2003.09.023

Bothma, J. du P., \& Du Toit, J. G. (2010). Game ranch management (5th ed.). Pretoria: Van Schaiks.

Caro, T. M. (1999). Conservation monitoring: estimating mammal densities in woodland habitats. Animal Conservation, 2(4), 305-315. http://dx.doi.org/10.1111/j.1469-1795.1999.tb00077.x

Caro, T. M., Pelkey, N., Borner, M., Campbell, K, L. I., Woodworth, B. L., Farm, B. P., ... Severre, E. L. M. (1998). Consequences of different forms of conservation for large mammals in Tanzania: preliminary analyses. African Journal of Ecology, 36, 303-320. http://dx.doi.org/10.1046/j.1365-2028.1998.00147.x

Caughley, G. (1977). Sampling in aerial survey. Journal of Wildlife Management, 41, 605-615. http://dx.doi.org/10.2307/3799980

Central Statistical Office. (2012). Zambia 2010 census of population and housing: population summary report. Lusaka: Central Statistical Office.

Chase, M., \& Griffin, C. (2008). Seasonal abundance and distribution of elephants in Sioma Ngwezi National Park, southwest Zambia. Pachyderm, 45, 88-97.

Chomba, C., Simukonda, C., Nyirenda V., \& Chisangano, F. (2012). Population status of the African elephant in Zambia. Journal of Ecology and the Natural Environment, 4(7), 186-193.

Craig, G. C. (2012). Monitoring the illegal killing of elephants: aerial survey standards for the MIKE programme. Nairobi: CITES MIKE programme.

Craigie, I. D., Baillie, J. E. M., Balmford, A., Carbone, C., Collen, B., Green, R. E., \& Hutton, J. B. (2010). Large mammal population declines in Africa's protected areas. Biological Conservation, 143, 2221-2228. http://dx.doi.org/10.1016/j.biocon.2010.06.007

Dunham, K. M. (2012). Trend in populations of elephant and other large herbivores in Gonarezhou National Park, Zimbabwe, as revealed by sample aerial surveys. African Journal of Ecology, 50(4), 476-488. http://dx.doi.org/10.1111/j.1365-2028.2012.01343.x

Ervin, J. (2003). Rapid assessment of protected area management effectiveness in four countries. BioScience, 53, 833-841. http://dx.doi.org/10.1641/0006-3568(2003)053\%5B0833:RAOPAM\%5D2.0.CO;2

Freemantle, T. P., Wacher, T., Newby, J., \& Pottorelli, N. (2013). Earth observation: overlooked potential to 
support species reintroduction programmes. African Journal of Ecology, 51(3), 482-492. http://dx.doi.org/10.1111/aje.12060

Garaï, M. E., Slotow, R., Carr, R. D., \& Reilley, B. (2004). Elephant reintroductions to small fenced reserves in South Africa. Pachyderm, 37, 28-36.

Hockings, M. (2003). Systems for assessing the effectiveness of management in protected areas. BioScience, 53(9), 823-832. http://dx.doi.org/10.1641/0006-3568(2003)053\%5B0823:SFATEO\%5D2.0.CO;2

Hockings, M., Stolton, S., \& Dudley, N. (2000). Evaluating Effectiveness: a framework for assessing the management of protected areas. Gland: The World Conservation Union (IUCN).

Hockings, M., Stolton, S., Leverington, F., Dudley, N., \& Courrau, J. (2006). Evaluating effectiveness: a framework for assessing management effectiveness of protected areas (2nd ed.) (Xiv, p. 105). Gland, Switzerland and Cambridge, UK: IUCN.

Jachmann, H. (2001). Estimating abundance of African wildlife: an aid to adaptive management. Boston: Kluwer Academic Publishers. http://dx.doi.org/10.1007/978-1-4615-1381-0

Jolly, G. M. (1969). Sampling methods for aerial censuses of wildlife populations. East African Agricultural and Forestry Journal, special issue, 34, 46-49.

Kruger, J. M., Reilly B. K., \& Whyte, I. J. (2008). Application of distance sampling to estimate population densities of large herbivores in Kruger National Park. Wildlife Research, 35, 371-376. http://dx.doi.org/10.1071/WR07084

Leverington, F., Costa, K. L., Courrau, J., Pavese, H., Nolte, C., Marr, M., ... Hockings, M. (2010). Management effectiveness evaluation in protected areas - a global study (2nd ed.). Brisbane: The University of Queensland.

Lewis, D., \& Phiri, A. (1998). Wildlife snaring - an indicator of community response to a community-based conservation project. Oryx, 32, 111-121. http://dx.doi.org/10.1017/S0030605300029859

Lindsey, P. A, Masterson, C. L., Beck, A. L., Romañach, S. (2012). Ecological, social and financial issues related to fencing as a conservation tool in Africa. In M. J. Somers, \& M. Hayward (Eds.), Fencing for Conservation (pp. 215-234). New York: Springer. http://dx.doi.org/10.1007/978-1-4614-0902-1_12

Lindsey, P. A., Balme, G., Becker, M., Begg, C., Bento, C., Bicchino, C., ... Zisadza-Gandiwa, P. (2013). The bushmeat trade in African savannas: impacts, drivers, and possible solutions. Biological Conservation, 160, 80-96. http://dx.doi.org/10.1016/j.biocon.2012.12.020

Margules, C. R., \& Pressey, R. L. (2000). Systematic conservation planning. Nature, 405, 243-253. http://dx.doi.org/10.1038/35012251

Martin, R. B. (2003). The influence of veterinary control fences on certain large mammal species in the Caprivi, Namibia. Windhoek: Namibia Nature Foundation.

Matthews, S., \& Brand, K. (2004). Africa invaded: the growing danger of invasive alien species. Western Cape: The Global Invasive Species Programme.

Mifsud, D. A., \& Thomas, J. C. (2013). Persistence of herpetofauna in the urbanized rouge river ecosystem. Open Journal of Ecology, 3(3), 234-241. http://dx.doi.org/10.4236/oje.2013.33027

Mulenga, C. N. (1990). Exploratory Soil Map, Lusaka Province (1: 1,000, 000). Lusaka: Survey Department.

Norton-Griffiths, M. (1978). Counting animals. Nairobi: African Wildlife Leadership Foundation.

Nyirenda, V. R., \& Nkhata, B. A. (2013). Collaborative governance and benefit sharing in Liuwa Plain National Park, Western Zambia. Parks, 19(1), 103-114.

Parrish, J. D, Braun, D. P., \& Unnasch, R. S. (2003). Are we conserving what we say we are? Measuring ecological integrity within protected areas. BioScience, 53(9), 851-860. http://dx.doi.org/10.1641/0006-3568(2003)053\%5B0851:AWCWWS\%5D2.0.CO;2

Peterman, W. E., Crawford, J. A., \& Kuhns, A. R. (2013). Using species distribution and occupancy modelling to guide survey efforts and assess species status. Journal for Nature Conservation, 21(2), 114-121. http://dx.doi.org/10.1016/j.jnc.2012.11.005

Plumptre A. J. (2000). Monitoring mammal populations with line transect techniques. Journal of Applied Ecology, 37, 356-368. http://dx.doi.org/10.1046/j.1365-2664.2000.00499.x 
Poulsen, J. R., Clark, C. J., Mavah, G., \& Elkan, P. W. (2009). Bushmeat supply and consumption in a tropical logging concession in northern Congo. Conservation Biology, 23, 1597-1608. http://dx.doi.org/10.1111/j.1523-1739.2009.01251.x

Pramod, A. F., Kumara, V., \& Gowda, R. H. T. (2012). Encounter rate of large mammals in Thanigebyle range Bhadra wildlife sanctuary, Karnataka. International Multidisciplinary Research Journal, 2(9), 9-11.

Racloz, V., Griot, C., \& Stärk, K. D. (2006). Review of sentinel surveillance systems with special focus on vector-borne diseases. Animal Health Research Reviews, 7, 71-79. http://dx.doi.org/10.1017/S1466252307001120

Reid, H.. (2001). Contractual national parks and the Makuleke community. Human Ecology, 29, 135-155. http://dx.doi.org/10.1023/A:1011072213331

Reilly, B. K. (2002). Precision of helicopter based counts in bushveld. Koedoe, 45(2), 77-83. http://dx.doi.org/10.4102/koedoe.v45i2.33

Rivero-Blanco, C., \& Gabaldon, M. (1999). The evaluation of natural protected area systems: a numeric method. Parks, 3, 11-13.

Salafsky, N., \& Margoluis, R. (1999). The threat reduction assessment (TRA): approach to measuring conservation success. A practical and cost-effective framework for evaluating project impact. Conservation Biology, 13, 830-841. http://dx.doi.org/10.1046/j.1523-1739.1999.98183.x

Sen, A. (1999). Development as Freedom. New York, NY: Anchor Books.

Simons, S., \& De Poorter, M. (2008). Best practices in pre-import risk screening for species of live animals in international trade. Proceedings of an expert workshop on preventing biological invasions (Vol. 9-11 April, p. 30). Indiana, USA: University of Notre Dame.

Sinclair, A. R., Fryxell, J. M., \& Caughley, G. (2009). Wildlife ecology, conservation and management. Malden, MA: Wiley-Blackwell Publishing.

Snyman, S. L. (2012). The role of tourism employment in poverty reduction and community perceptions of conservation and tourism in Southern Africa. Journal of Sustainable Tourism, 20, 395-416. http://dx.doi.org/10.1080/09669582.2012.657202

Stolton, S., Hockings, M., Dudley, N., MacKinnon, K., Whitten, T., \& Leverington, F. (2007). Reporting progress in protected areas: a site-level management effectiveness tracking tool (2nd ed.). Gland: World Wide Fund for Nature (WWF).

Storm, D. J., Samuel, M. D., Van Deelen, T. R., Malcolm, K. D., Rolley, R. E., Frost, N. A., ... Richards, B. J. (2011). Comparison of visual-based helicopter and fixed-wing forward looking infrared surveys for counting white-tailed deer Odocoileus virginianus. Wildlife Biology, 17, 431-440. http://dx.doi.org/10.2981/10-062

Struhsaker, A. R., \& Jacobson, S. K. (2004). Threat reduction assessment of conventional and community-based conservation approaches to managing protected areas in Uganda. Environmental Conservation, 31, 133-241.

Stuart, C., \& Stuart, M. (2013). A field guide to the tracks and signs of Southern, Central and East African wildlife (4th Ed.). Cape Town: Struik Nature.

The Nature Conservancy. (2000). The five - S framework for site conservation. A practitioner's handbook for site conservation planning and measuring conservation success. Vol. 1. (2nd ed.).

Van Wilgen, B. W., Everson, C. S., \& Trollope, W. S. W. (1990). Fire management in Southern Africa: some examples of current objectives, practices and problems. In J. G. Goldammer (Ed.), Fire in the tropical biota: ecosystem processes and global challenges. Ecological Studies 84 (pp. 216-272). Berlin: Springer-Verlag. http://dx.doi.org/10.1007/978-3-642-75395-4_11

Varman, K. S., \& Sukumar, R. (1995). The line transect method for estimating densities of large mammals in a tropical deciduous forest: an evaluation of models and field experiments. Journal of Biosciences, 20(2), 273-287. http://dx.doi.org/10.1007/BF02703274

Watson, F., Becker, M. S., McRobb, R., \& Kanyembo, B. (2013). Spatial patterns of wire-snare poaching: implications for community conservation in buffer zones around National Parks. Biological Conservation, 168, 1-9. http://dx.doi.org/10.1016/j.biocon.2013.09.003 
Yachiyo Engineering Co. Ltd. (1995). The study on the National Water Resources Master Plan in the Public of Zambia. Lusaka: JICA-MEWD.

\section{Copyrights}

Copyright for this article is retained by the author(s), with first publication rights granted to the journal.

This is an open-access article distributed under the terms and conditions of the Creative Commons Attribution license (http://creativecommons.org/licenses/by/3.0/). 